\title{
Roman Catholic Approaches to Other Religions: Developments and Tensions
}

\author{
Paul F. Knitter
}

A missiological authority, well known and respected by readers of this journal, has recently indicated and predicted "radical changes" in Roman Catholic mission theology and in its attitude toward other religions:

\begin{abstract}
... Roman Catholic mission theology has undergone more radical change in these fifteen years than in the previous century. And there is obviously a great deal more ferment to come in the last fifth of the twentieth century. What we see so far, in my judgment, is but a foretaste or the first fruits of a radical realignment of Catholic mission theology that by A.D. 2000 will be as far from our thinking today as our thinking today is from where Catholic mission theology was twenty years ago. ${ }^{1}$
\end{abstract}

The following bird's-eye survey of five stages in the evolution of Catholic theology of religions will prove, I hope, how correct Gerald H. Anderson's assessment is. Given the limitations of a short article, I cannot do much more than describe the general content and the main representatives of each stage, with greater attention given to the newer, less-known developments. The intent of such a broad overview is to provide a sense of historical evolution that will enable us to understand and evaluate present developments and tensions.

\section{Historical Background: From Exclusive to Inclusive Ecclesiocentrism}

From the start, Christian theologians have had a hard time reconciling universality with particularity, that is, God's universal will to save with the particular mediation of that will in Jesus, word, and church. The early fathers held to a fairly common opinion that an authentic revelation and possiblity of salvation were available to all peoples (based especially on the doctrine of "the seminal word"). This opinion soon lost currency. Especially under the imposing influence of Augustine and his anti-Pelagian polemic, and then in the heat of battle against the "paganism" of Islam, the prevalent attitude toward other religions from the fifth century through the Middle Ages (even for Aquinas) was that "outside the church there is no salvation." 2 The Council of Florence (1442) officially declared that "no one, whatever almsgiving he has practiced, even if he has shed blood for the name of Christ, can be saved, unless he has remained in the bosom and unity of the Catholic Church."3

The Council of Trent signaled a "radical change" in the exclusive ecclesiocentrism of the Middle Ages. Especially in light of the newly discovered peoples who had never heard of Christ, the council allowed that "baptism of desire" could admit into the church anyone who lived a moral life but could not receive baptism of water. "This more optimistic attitude toward the "pagans" characterized, for the most part, Roman Catholic attitudes from

Paul F. Knitter is Professor of Theology at Xavier University, Cincinnati. He is the author of Towards a Protestant Theology of Religions (1974) and numerous journal articles on religious pluralism. His recent survey and evaluation of Christian attitudes toward other religions will be published by Orbis Books. the sixteenth to the twentieth centuries. What took place was a significant shift in Catholic theology from an exclusive to an inclusive understanding of the church as the sole channel of grace. In other words, Catholic belief moved from holding "outside the church no salvation" to "without the church no salvation." During the first half of the twentieth century, Catholic theologians came up with ingenious concepts to include within the church any trace of salvation outside it: saved non-Christians belonged to the "soul" of the church; they were "attached," "linked," "related" to the church; they were members "imperfectly," "tendentially," "potentially."5

Historians often forget that this positive shift in Catholic attitudes toward "pagans" did not include a more positive attitude toward pagan religions. Very few theologians ventured the assertion that universally available grace might be available through the religions. The experience of God's grace, always an ecclesial affair for Catholics, was evidently a private affair for pagans. ${ }^{6}$

\section{Constitutive Christocentrism: Christ in the Religions (Vatican II and Karl Rahner)}

Vatican Council II continued the inclusive ecclesiocentrism of the previous period. While the council fathers reaffirmed that the church is necessary for salvation, they also, as it were, extended the universal possibility of salvation-even atheists could be saved. $^{7}$ Yet the council, as is well known, took a definitely new turn when, for the first time in the history of official church statements, it praised individual world religions for the way they reflect "that Truth which enlightens every person."8 The majority of Catholic thinkers interpret the conciliar statements to affirm, implicity but clearly, that the religions are ways of salvation. These theologians endorse the theology of religions elaborated by Karl Rahner, whose thought so strongly influenced the council's deliberations. In Rahner, and in his endorsers, we see another radical change in Catholic theology of religions.

The main ingredients in Rahner's optimistic assessment of other religions are well known. They are two: God's universal salvific will (grounding what Rahner terms a "salvific optimism" for all humanity) and humanity's essentially social nature. Combining the two ingredients: if God wills to grant grace to every person, this grace must take on a sociohistorical "body" in order to be really available; and among the most likely mediating bodies for grace are the religions. The religions therefore are or can be "grace-filled" ways of salvation and are "positively included in God's plan of salvation." What enables Rahner to draw this conclusion is his subtle but significant shift from ecclesiocentrism to Christocentrism.

This shift is embodied in Rahner's much discussed model of anonymous Christianity (which, as his critics often forget, he intended only for Christian consumption, not for proclamation to outsiders). The model's first intent is to remind Christians that God's saving presence "is greater than man and the Church"; grace can, as it were, float free of the visible church and incarnate itself in other words and sacraments. But for Rahner, if grace is not bound to the church, it is bound to Christ. Jesus of Nazareth is the constitutive cause of all salvation. As the full and final manifestation of God's saving presence in history, he is both the cause (final 


\section{International Bulletin of Missionary Research}

Established in 1950 as Occasional Bulletin from the Missionary Research Library. Named Occasional Bulletin of Missionary Research 1977. Renamed International Bulletin of Missionary Research 1981.

Published quarterly in January, April, July and October by the

Overseas Ministries Study Center

6315 Ocean Avenue, Ventnor, New Jersey 08406, U.S.A.

Telephone: (609) 823-6671

Editor:

Gerald H. Anderson

Associate Editor:

James M. Phillips

Catalino G. Arévalo, S.J.

Contributing Editors:

David B. Barrett

R. Pierce Beaver

Norman A. Horner

Mary Motte, F.M.M.

Lesslie Newbigin

C. René Padilla

Thomas F. Stransky, C.S.P.

Charles R. Taber

Desmond Tutu

Anastasios Yannoulatos

Books for review and correspondence regarding editorial matters should be addressed to the editors. Manuscripts unaccompanied by a self-addressed, stamped envelope (or international postal coupons) will not be returned.

Subscriptions: $\$ 14.00$ for one year, $\$ 26$ for two years, and $\$ 37$ for three years, postpaid worldwide. Individual copies are $\$ 5.00$; bulk rates upon request. Correspondence regarding subscriptions and address changes should be sent to: International Bulletin of Missonary Research, Circulation Department, P.O. Box 1308-E, Fort Lee, New Jersey 07024-9958.

Advertising:

Ruth E. Taylor

11 Graffam Road, South Portland, Maine 04106

Telephone: (207) 799-4387

Articles appearing in this journal are abstracted and indexed in:

Bibliografia Missionaria

Christian Periodical Index

Guide to Social Science and Religion in Periodical Literature

Missionalia

Religion Index One: Periodicals

Religious and Theological Abstracts

Opinions expressed in the International Bulletin are those of the authors and not necessarily of the Overseas Ministries Study Center.

Copyright (c) 1984 by Overseas Ministries Study Center. All rights reserved.

Second-class postage paid at Atlantic City, New Jersey.

POSTMASTER: Send address changes to International Bulletin of Missionary Research, P.O. Box 1308-E, Fort Lee, New Jersey 07024.

\section{ISSN 0272-6122}

cause) and the goal of every experience of God. Grace, therefore, is always Christ's, always oriented toward Christ and toward Christ's continued embodiment in the church. (In this sense, Rahner continues to claim the "necessity" of the church.) In the final analysis, then, the religions are incomplete without Christ; they must be fulfilled in him and his church; they are a praeparatio evangelica, a preparation for the gospel. The missionary mandate remains intact and is reinforced. ${ }^{10}$

Vatican II's statements on other religions, as interpreted by Rahner, embody the mainline view of Roman Catholic theologians, even though they may not expressly use the model of anonymous Christianity. Edward Schillebeeckx, Pietro Rossano, Avery Dulles, Richard McBrien, even Pierre Teilhard de Chardin affirm the universality of Christ and his grace and the religions as mediators of that grace. ${ }^{11}$ Because these theologians continue to hold to Christ as the one Savior and constitutive cause of salvation, they view the religions as already partially containing Christ's grace, but as incomplete until fully incorporated into Christ and his church.

\section{Normative Christocentrism: Christ above the Religions (A New Direction)}

Although most contemporary Roman Catholic theologians readily accept the basics of the mainline approach to other religions, many are uneasy with the way it seems to judge religions before really listening to them, especially by predefining them as anonymous Christians. This uneasiness has given rise to another realignment in Catholic attitudes toward religions; there is a shift beyond Vatican II and Rahner, toward a clearer recognition of the independent value and enduring mission of other faiths. The underlying, often implicit, theological foundation for this shift is a new understanding of Christ's (and the church's) salvific role.

Hans Küng speaks for many in his criticism of the anonymous-Christianity model. For Küng, this theory is but a "theological fabrication," intended to save the "infallible formula" of outside-the-church-no-salvation. To view other believers as Christians without a name is an offense to them and an obstacle to Christians' ability genuinely to listen to what these others have to say. Küng urges Christians to admit, honestly, that the church is not necessary for salvation. With $\mathrm{H}$. R. Schlette he describes the religions as the "ordinary," or common, way to salvation, while Christianity makes up the "extraordinary," or special, way. ${ }^{12}$

Other Roman Catholic theologians complement Küng's views when they suggest that perhaps it is not God's will that all peoples enter the Christian fold; perhaps "religious pluralism is the will of God for humanity." This implies that the other religions and Christiantiy may be parallel paths to salvation, with any final convergence reserved for the eschaton. ${ }^{13}$ In this view, the accepted image of the church as the "Sacrament of salvation" means that the primary mission of the church is not to bring redemption but "epiphany," not to win conversions to the church as the necessary means of salvation but to help build the broader kingdom of God as it takes shape within history. Furthering the kingdom might well mean making Buddhists better Buddhists. ${ }^{14}$

Another aspect of this new shift among Catholic theologians is seen in their approach to dialogue. They suggest that Christians should speak with other believers not only to reveal points of agreement or conflict, not only to understand more profoundly what they (Christians) already have in Christ, but also to discover genuinely new pieces of the mosaic of God's universal revelation. ${ }^{15}$ Such a view implies that God has more to say than what was said in the Christian word.

As Peter Schineller has pointed out, implicit in this new atti- 
tude toward other religions is a move away from understanding Christ as "the constitutive, unique ... mediator of salvation for all mankind." Just as Rahner no longer tied universal saving grace to the church, many Roman Catholic theologians no longer tie it to Christ. Therefore they feel no pressing need to identify other believers as anonymous Christians or to usher them into the church. Yet despite this Christological shift and its intent to let the religions stand on their own, all the theologians exploring this new direction continue to affirm Jesus Christ as God's normative revelation. Jesus and the gospel remain the "superior or ideal type, which can function to measure, correct, and judge others by its own standards." 16

So Küng, after denouncing common Christian attitudes toward other believers as "arrogant domination ... [and] absolutism," himself proclaims Christ as "ultimately decisive [and] definitive" and as providing the "critical catalyst" without which the religions cannot really adjust to the modern world. For Küng, other believers may not be anonymous but they are potential Christians. ${ }^{17}$ Other theologians (H. R. Schlette, Bernard Lonergan,

\section{"God has more to say than what was said in the Christian word."}

William Thompson, and more recently Walbert Bühlmann and Arnulf Camps), who call for a greater recognition of the independent validity of other faiths, continue to affirm Jesus Christ as bearing an "absolute quality," as "God's definitive manifestation," as "unsurpassable."18 This recognition of the independent validity of other religions, together with the continued affirmation of Christ/Christianity's normativeness, makes up what might be called a growing common opinion among Catholic theologians.

\section{Dialogical Theocentrism: Many Religions/ Partners in God (A Minority View)}

Another group of Catholic thinkers, still a minority, detect a tension, even a contradiction, between the previous view's more positive approach to other faiths and its insistence on the normativeness of Chirst. In trying to resolve this tension, these minority theologians epitomize the "great deal more ferment" that Gerald H. Anderson predicted in Catholic mission theology. These theologians, all of whom are veterans in the actual arena of interreligious dialogue, try to show how Christians can encounter other believers with a clear affirmation of Christ's universal salvific role without having to claim his normativeness and finality. In somewhat greater detail, let us consider three examples of this new ferment.

1. Raimundo Panikkar is one of the most learned and experienced adoocates of a reoised understanding of Christ and religions. Within the "ecumenical ecumenism" that he has promoted over the past two and a half decades, he has revised his earlier view that Christianity is "the end and plenitude of every religion." In the completely revised 1981 edition of his The Unknown Christ of Hinduism and in statements since the early 1970s, he affirms that no religion can enter the dialogue with claims of final or absolute normativeness. ${ }^{19}$ He now advocates "an authentically universal Christology," which makes use of traditional Logos Christology and presses the distinction between the Christ (Logos) and the historical Jesus. Christ/Logos is the universal bond between humanity/ world and God-the self-communicating, unifying outreach of the Ultimate. As to the relation between Christ and Jesus, Panikkar states succinctly: "Christ the Savior is ... not to be restricted to the merely historical figure of Jesus of Nazareth. ... Though a Christian believes that 'Jesus is the Christ' ... this sentence is not identical to 'the Christ is Jesus'..." From his own Christian and interreligious experience, Panikkar holds that Christians can allow for other historical names and manifestations of the Christ, without lessening their personal commitment to Jesus as the Christ or to the urgency of making him known to all. ${ }^{20}$ With such an approach, Christian mission consists both in witnessing and in being witnessed to.

2. Another clear call for revisions in traditional views of Christ and other religions is sounded by Catholic theologians engaged in the dialogue with Judaism: Gregory Baum, Monika Hellwig, John Pawlikowski, Rosemary Ruether. While their particular perspectives differ, they are unanimous in insisting that insofar as Christian understanding of Christ has led to a "supersessionist," subordinating approach to Judaism, "our traditional Christology is severely inadequate" and must be "significantly rethought."21 In different ways, all of them appeal to Christians to modify their understanding of Christ as the final Messiah, that is, as he who has brought about the final, normative realization of the kingdom.

Baum argues that until the last days are upon us, all absolute, final assertions about Christ should be avoided. ${ }^{22}$ Hellwig points out that all Christian talk about Christ is religious, existential language that should not be turned into absolute, ontological claims for all peoples and times. ${ }^{23}$ Ruether proposes that the death and resurrection of Jesus be seen as a salvific paradigm of hope and transforming praxis that exists alongside other salvific paradigms. ${ }^{24}$ Pawlikowski wants to safeguard the uniqueness of the Christ-event, which, he feels, Judaism would do well to recognize; but he also admits the uniqueness of Judaism, which must complement and complete Christianity. ${ }^{25}$ Again, all of these theologians hold that a relativizing of Jesus' finality does not lessen his universal relevance. In their minds, Christian commitment to and witness of Jesus remain robust.

3. Some of the boldest proposals for a revision of approaches to other religions are sounded by Third World mission theologians such as Ignace Puthiadam, Henri Maurier, and Aloysius Pieris. All three give painful witness to how traditional Christian claims of having a "normative, complete, definitive" revelation in Christ have made Christian dialogue with other faiths an encounter "between the cat and the mouse." 26 Pieris reduces all given Christian approaches to other faiths to two models: either the "Christ-against-religion" model (neo-orthodox, evangelical, as well as Latin American liberation theologies) or the "Christ-of-religions" model (Catholicism's anonymous-Christian theory as well as India's and the World Council of Churches' cosmic Christology). Both approaches conceal a "crypto-colonialist theology of religions ... that keeps our revolutionary rhetoric from resonating in the hearts of the Third World non-Christian majorities." 27 All three theologians, therefore, suggest that Christians, under the pressure of a more effective witness to other believers, examine how they have falsely absolutized Christ.

Puthiadam and Maurier propose a model for mission and dialogue that recognizes unique, universally meaningful truth in each religion (and each "savior"); yet each "unique" religion or revealer is not excluded or relativized by the other, but essentially related to the other. All religions, in their real differences and otherness, are related to each other as a "coincidence of opposites"; they are in need of each other in order to carry on, together, their common 
pilgrimage toward the Divine Mystery, the "Source and Goal" that animates them all. The primary goal of mission, then, is not conversion (though that is not excluded), but mutual witnessing. ${ }^{28}$

For Pieris the basis and framework for Christian mission and religious encounter should not be Christology (presupposing Christ to be either against or already within other religions) or theology (exploring whether/how other religions recognize. God). Rather, Christian approaches to other faiths should be grounded in soteriology, in the "ineffable mystery of salvation," which for Pieris is the divine urge and impulse to liberate and generate "a new humanity." All religions, including those of the East, share in and contribute to this liberating mystery, which is the only real "absolute" in religious encounter. Mission and dialogue should be based on collaboration with other believers in this mystery. Theological clarifications about the uniqueness of Jesus can follow. ${ }^{29}$

This most recent shift in Roman Catholic theology of religions incorporates a clearly theocentric perspective. It is both distant from and yet continuous with the ecclesiocentrism and Christocentrism of earlier Catholic views. While continuing to affirm Jesus as a savior for all peoples of all times, together with the church as the community by which Jesus' presence and message is embodied through time, these Third World theologians see all religions as partners in a salvific dialogue in which not the church or Jesus, but God, the "mystery of salvation", is the final ground and goal and norm.

\section{Conclusion:}

In tracing the radical changes throughout the history of Catholic attitudes toward other religions, one detects a certain evolution from ecclesiocentrism to Christocentrism and, most recently, to theocentrism. The central question for Catholics and all Christians is whether this evolution has been toward more abundant life or, at any point in its unfolding, it has arrived at dead ends. This question applies especially to the new, theocentric approach. At stake is the integrity of the gospel, the quality of Christian com-

\section{"One detects a certain evolution from ecclesiocentrism to Christocentrism and, most recently, to theocentrism."}

mitment, and the vitality of Christian mission. To discern whether the evolution we have studied is life-giving, Catholic theologies of religions need to be tested agaist three criteria: Do they enable Christians to hear more adequately the witness of Scripture? Do they lead the Christian faithful to a deeper commitment to Christ and the gospel? And especially, do they inspire Christians to carry out more effectively their essential mission of advancing God's kingdom by witnessing to God's Christ? To carry out this task of discernment, Catholic theologians need support and criticism from their brothers and sisters in other churches. The intent of this study is to promote that kind of inner-Christian dialogue.

\section{Notes}

1. Gerald H. Anderson, in Christ's Lordship and Religious Pluralism, ed. Gerald H. Anderson and Thomas F. Stransky (Maryknoll, N.Y.: Orbis Books, 1981), p. 110.

2. Augustine, Enchiridion, 107. Aquinas. Summa Theologica, II, II, q. 2, art. 5, ad 1; III, q. 61, art. 1; II, q. 2, art. 7.

3. H. Denzinger, Enchiridion Symbolorum Definitionum et Declarationum, sects. ed. 33 by A. Schönmetzer (Freiburg i. Br.: Herder, 1965), sect. 1351.

4. Ibid., 1524, 1542.

5. Maurice Eminyan, The Theology of Saloation (Boston: St. Paul Editions, 1960), pp. 167-81.

6. Notable exceptions to this disregard of the possible value of other religions were Nicholas of Cusa (1464), Matteo Ricci (1610), Robert de Nobili (1656), and more recently, Otto Karrer in his Religions of Mankind (New York: Sheed \& Ward, 1936).

7. Lumen Gentium, 14, 16; Unitatis Redintegratio, 3.

8. Nostra Aetate, 2.

9. Karl Rahner, Theological Investigations, 14 vols. (New York: Crossroad, 1964), vol. 5, pp. 121-30; Foundations of Christian Faith (New York: Crossroad, 1978), pp. 315-16, 40-41.

10. Rahner, Theological Investigations, vol. 5, pp. 118, 122, 131-34; vol. 6, pp. 390-95; vol. 12, pp. 161-78.

11. Schillebeeckx, "The Church and Mankind," Concilium, 1 (1965); pp. 36 , 43-47; Rossano, "Christ's Lordship and Religious Pluralism in Roman Catholic Perspective," in Christ's Lordship, ed. Anderson and Stransky, pp. 96-110; Dulles, Models of Revelation (New York: Doubleday, 1983), pp. 189-92; McBrien, Catholicism (Oak Grove, Minn.: Winston Press, 1981), pp. 269-71, 290; Ursula King, "Religion and the Future: Teilhard de Chardin's Analysis of Religion as a Contribution to Inter-Religious Dialogue," Religious Studies 7 (1971): 307-23.
12. Küng, On Being a Christian (New York: Doubleday, 1976), pp. 97-98; "The World Religions in God's Plan of Salvation," in Christian Reoelation and World Religions, ed. Joseph Neuner (London: Burns \& Oates, 1967), pp. 31-37, 51-53; H. R. Schlette, Towoards a Theology of Religions (New York: Herder \& Herder, 1965), pp. 80-81.

13. Gregory Baum, "Christianity and Other Religions," Cross Currents 16 (1966): 461; Piet Schoonenberg, "The Church and Non-Christian Religions," in The Eoolving Church, ed. D. Flanagan (Staten Island, N.Y.: Alba House, 1966), pp. 97-99; Eugene Hillman, The Wider Ecumenism (New York: Herder \& Herder, 1968), pp. 60-61; Ignace Puthiadam, "Christian Faith and Life in a World of Religious Pluralism," Concilium, 135 (1980); $105-6$.

14. Schlette, Towards a Theology of Religions, pp. 83-93; Hillman, The Wider Ecumenism, pp. 81-158; Roger Haight, "Mission: The Symbol for Understanding the Church Today," Theological Studies, 37 (1976): 620-48.

15. Schoonenberg, The Church and Non-Christian Religions, pp. 100-107; Küng, On Being a Christian, pp. 112-16.

16. J. Peter Schineller, "Christ and the Church: A Spectrum of Views," Theological Studies 37 (1976): 555-57.

17. Küng, On Being a Christian, pp. 106-15, 123-24; "The World Religions," pp. 57-66.

18. Schlette, Towards a Theology of Religions, pp. 93-96; Lonergan, Method in Theology (New York: Seabury Press, 1972), pp. 112-13, 119; Bühlmann, The Chosen People (Maryknoll, N.Y.: Orbis Books, 1983), pp. 207, 219-22; Camps, Partners in Dialogue: Christianity and Other World Religions (Maryknoll, N.Y.: Orbis Books 1983), pp. 33-34, 48, 54, 113, 155; Thompson, "The Risen Christ, Transcultural Consciousness and the Encounter of the World Religions," Theological Studies 37 (1976): 381-409. 
19. Panikkar, The Trinity and the Religious Experience of Man (Maryknoll, N.Y.: Orbis Books 1973), p. 55; The Unknown Christ of Hinduism (Maryknoll, N.Y.: Orbis Books, 1981), pp. 75-96; "The Category of Growth in Comparative Religions," Haroard Theological Review 66 (1973): 113-40; "Christianity and World Religions," in Christianity (Patiala, India: Punjab Univ., 1969), pp. 78-127.

20. Panikkar, Saloation in Christ (Santa Barbara, Calif.: privately published, 1972), pp. 51-62, 71-72; The Trinity, pp. 53-54; The Unknown Christ, pp. 8-9, 14, 27, 48.

21. John Pawlikowski, Christ in the Light of the Christian-Jewish Dialogue (New York: Paulist Press, 1982), p. 7.

22. Baum, "Introduction" to R. Ruether, Faith and Fratricide: The Theological Roots of Anti-Semitism (New York: Seabury Press, 1974).

23. Hellwig, "Christian Theology and the Covenant of Israel," Journal of Ecumenical Studies 7 (1970): 49.
24. Ruether, Faith and Fratricide, pp. 249, 256; To Change the World: Christology and Cultural Change (New York: Crossroad Publishing Co., 1981), pp. 42-43.

25. Pawlikowski, Christ in the Light, pp. 113-18, 121-25, 149.

26. Puthiadam, "Christian Faith and Life," pp. 103-5, 110-11; Maurier, "The Christian Theology of the Non-Christian Religions," Lumen Vitae 21 (1976): 60.

27. Pieris, "The Place of Non-Christian Religions and Cultures in the Evolution of Third World Theology," in Irruption of the Third World: Challenge to Theology, ed. Virginia Fabella and Sergio Torres (Maryknoll, N.Y.: Orbis Books 1983), pp. 114-22; "Speaking of the Son of God in NonChristian Cultures, e.g. in Asia," Concilium 153 (1982): 66-67.

28. Puthiadam, "Christian Faith and Life," pp. 107-11; Maurier, "The Christian Theology," pp. 71-74.

29. Pieris, "The Place," pp. 133-34; "Speaking," pp. 67-68.

\section{Christianity and Judaism: Continuity and Discontinuity}

\section{W. S. Campbell}

$\mathbf{T}$ he relationship between Christianity and Judaism is a vast theme. Some of the most significant developments affecting the relationship have originated from historical events such as the Jewish-Roman war and the eventual destruction of Jerusalem; the Holocaust is a more recent example. In this study we shall confine ourselves to theological issues in three key topics: covenant, Paul's conversion-call, and the use of the title "Israel." The aim is to demonstrate that continuity as well as discontinuity between Christianity and Judaism is basic to the New Testament understanding of all three.

\section{New Covenant or Renewed Covenant?}

The ambiguity concerning the understanding of "covenant" in the New Testament is illustrated by the variation both in the meaning and in the frequency of the term. Of the thirty-three occurrences, eight are in the undisputed letters of Paul, seventeen are in Hebrews, with four occurrences in Luke/Acts, and one each in Mark, Matthew, Ephesians, and Revelation.

Paul first uses the adjective new (kaine $)$ in connection with covenant (diatheke $\bar{e}$ ) in the reference in 1 Corinthians 11:25 to the institution of the Lord's Supper. Mark simply refers to "my blood of the covenent" (14:24). In the earliest and best manuscripts of Matthew and Mark, "new" is not included. Luke 22:17-20 includes two traditions-a shorter one that does not mention "covenant" at all, and a longer one that mentions "the new covenant." The sole reference to "the old covenant" is found in 2 Corinthians 3:14 where Paul speaks of reading the old covenant. It is probable that behind the references to "new covenant" in the New Testament is the passage in Jeremiah 31:31-34 where the prophet says, "Behold, the days are coming, says the Lord, when I will make a new covenant with the house of Israel and the house of Judah." The significant feature of this covenant, which will distinguish it from that

W. S. Campbell, a minister of the United Reformed Church, studied at Edinburgh and Tübingen universities where his research was on Paul's Letter to the Romans, particularly chapters 9-11. He is presently Head of Religious and Theological Studies at Westhill College, Selly Oak Colleges, Birmingham, U.K. made at the exodus, is that the Lord will put his law within them: "I will write it upon their hearts." If Jesus did actually use the phrase "new covenant," probably he had this prophecy in mind.

\section{"Covenant" in Hebrews}

This epistle cites the Jeremiah passage in full (from the Septuagint) in Hebrews 8:8-12. The author has more than one meaning for the word diathêke $\bar{e}$, he can use it as meaning a "testament," associated with the death of the testator (9:16f.). Hebrews offers a clear contrast between the old and the new, but, unlike Paul or Jeremiah, its author finds the essence of the two diathekai in the cultic aspect. This approach is doubtless to be understood in light of the purpose and the audience for which the document was originally written. The interpretation of Hebrews will differ depending on whether the author is seen as contrasting Christian faith with Judaism or with some Jewish-Gnostic heresy.

In his recent Introduction to the New Testament, H. Koester suggests that the author of Hebrews, addressing the whole Christian church, enters into a critical theological controversy with Gnosticism by refuting the Gnostic understanding of both the redeemer and the process of salvation by means of a Christological and ecclesiological interpretation of Scripture. ${ }^{1}$ In his commentary on Hebrews, Robert Jewett notes the close parallels between Colossians and Hebrews; the key argument in both is that Christ has overcome the elemental forces of the universe. He takes up the proposal of Charles P. Anderson that the lost Laodicean letter, written probably by Epaphras, is in fact the Epistle to the Hebrews (cf. Col. 4:16). ${ }^{2}$

The fact that the most recent scholarship considers the purpose of Hebrews as being essentially to oppose a Jewish-Gnostic type of heresy means that we must be extremely careful not to read this letter simply as a stark contrast between Judaism ("the old") and Christianity ("the new") as symbolized by two distinct covenants. Koester in fact warns that parts of Hebrews may be completely misunderstood if the letter is interpreted as a criticism of the Jewish cult. He states: "To be sure, the material and temporal limitations of the sacrificial cult are pointed out (9:9-10), but the actual point of the argument as a whole is to prove that the 